\title{
Integrated control of Striga hermonthica (Del.) Benth. in Burkina Faso through host plant resistance, biocontrol and fertilizers
}

\author{
D. YONLI ${ }^{1 *}$, H. TRAORÉ ${ }^{1}$, T.A. VAN MOURIK ${ }^{2}$, D.E. HESS ${ }^{3}$, P. SÉRÉMÉ $^{1}$ and \\ P. SANKARA ${ }^{4}$
}

\author{
${ }^{1}$ Institut de l'Environnement et de Recherches Agricoles, 04 B.P. 8645 Ouagadougou 04, Burkina Faso. \\ ${ }^{2}$ International Crops Research Institute for the Semi-Arid Tropics, ICRISAT-Bamako, BP 320, Bamako, Mali. \\ ${ }^{3}$ Merry Lea Environmental Learning Center of Goshen College, P.O. Box 263, Wolf Lake, IN 46796, \\ United States of America. \\ ${ }^{4}$ Unité de Formation et de Recherches en science de la vie et de la Terre, B.P. 7021, Ouagadougou, \\ Burkina Faso. \\ *Corresponding author, E-mail: d.yonli313@gmail.com
}

\begin{abstract}
A two-year field study investigated integrated management of Striga hermonthica on sorghum through host crop resistance, biocontrol (Fusarium oxysporum isolate 34-FO), and fertilizer application. The experiment was conducted in a field with natural Striga infestation at Kouare Research Station in Fada N'Gourma, Burkina Faso. Treatments combining sorghum resistance with Fusarium inoculum and N-fertilizer or manure significantly reduced emerged Striga plant number, plant vigour and dry biomass of Striga and the area under the Striga number progress curve (ASNPC) in 2002, as compared to the control. Integrated Striga Management (ISM) plots fertilized with urea, urea plus growth medium or urea plus manure associated with Fusarium inoculum resulted in improved sorghum grain yield of at least $15 \%$ in 2001 and of at least $97 \%$ in 2002. Economic analysis showed that the combination of sorghum resistance with fungal inoculum or urea at $200 \mathrm{~kg} \mathrm{ha}^{-1}$ allowed for a significant financial profit in sorghum production. The results suggest that to reduce Striga infestation below economic threshold, ISM treatments should be consistently applied for several years without expecting very high returns.
\end{abstract}

() 2011 International Formulae Group. All rights reserved.

Keywords: Striga hermonthica, integrated control, Fusarium inoculum, Sorghum resistance, fertilization, Burkina Faso.

\section{INTRODUCTION}

Striga hermonthica, the most economically important parasitic weed in the world, is endemic to the African savannah and the Sahel where it can devastate the yields of cereal crops (Parker and Riches, 1993). S. hermonthica parasitizes all rain fed graminaceous crops in this region but is particularly problematic on sorghum, pearl millet and maize, the major staple cereals of over 300 million people in sub-Saharan Africa (Scholes and Press, 2008). Crop yield losses 
due to Striga parasitism have been estimated at 10.7 million tons per year in sub-Saharan Africa (Gressel et al., 2004). The methods most commonly used by farmers to control Striga in Burkina Faso are hand-pulling, crop rotation, and fallow, but these practices seldom lead to long-term reductions in the populations of $S$. hermonthica in infested fields (Traoré and Yonli, 2001). Sorghum varieties with some resistance to $S$. hermonthica have been reported in Burkina Faso (Olivier et al., 1992) but no sorghum variety has so far shown complete resistance to the parasite. Consequently, small-scale farmers mostly rely on local sorghum varieties tolerant of Striga infestation, although their cultivation may lead to ever increasing Striga seed-bank densities in the soil (Van Mourik et al., 2008). Continuous cultivation and limited application of mineral and organic fertilizers have led to depletion of soil nutrients and soil degradation. These conditions combine to favour establishment and increase of Striga hermonthica populations, with devastating effects on cereal production. Nowadays, an integrated approach to Striga management is gaining popularity and generally favoured over the use of any single control method (Van Mourik, 2007). The use of soil-borne micro-organisms as biocontrol agents of Striga has been investigated in the region. Fungi (Abbasher et al., 1998; Marley et al., 2004; Yonli et al., 2004, 2006) and bacteria (Ahonsi et al., 2002) have been suggested as components of integrated Striga management strategies. Ciotola et al. (2000) concluded from their work that the use of Fusarium oxysporum (isolate M12-4A) combined with other control measures could contribute to an effective strategy of control Striga.

The field study reported here investigated the effects of fungal inoculum based on $F$. oxysporum isolate 34-FO combined with host plant resistance and fertilizer use on crop yield and control of Striga.

\section{MATERIALS AND METHODS}

\section{Site, characteristics and genetic material}

The study was conducted during the 2001 and 2002 cropping seasons at the INERA (Institut de l'Environnement et de Recherches Agricoles) Kouaré Research Station (11 ${ }^{\circ} 95^{\prime} 03^{\prime \prime} \mathrm{N}$ and $\left.0^{\circ} 30^{\prime} 58^{\prime \prime} \mathrm{E}\right)$ at Fada $N^{\prime}$ Gourma in the eastern Sudan-Savannah region of Burkina Faso. Trials were implemented on a sandy-loam, tropical, ferruginous soil. Experimental plots were chosen with a heavy natural infestation of $S$. hermonthica (at least 30 emerged plants $\mathrm{m}^{-2}$ in the previous year) (Yonli et al., 2004).

Seeds of the Striga-susceptible sorghum variety S 29 and Striga-resistant sorghum variety F2-20 were obtained from the national breeding program. Fusarium oxysporum isolate $34-\mathrm{FO}$ demonstrated its efficacy in killing Striga in previous studies (Yonli et al., 2006, 2010). Fungal inoculum was prepared using the technique described by Yonli et al. (2006). The growth medium (compost) was produced from crop residues, cow dung, Burkina rock phosphate and water according to the method of Sedogo et al. (1999) and autoclaved at $120{ }^{\circ} \mathrm{C}$ for 1 hour before inoculating with $F$. oxysporum isolate 34-FO.

The chemical composition of the compost used in 2001 was: $16.72 \%$ carbon, $1.50 \%$ nitrogen $(\mathrm{N}), 0.52 \%$ phosphorus $\left(\mathrm{P}_{2} \mathrm{O}_{5}\right)$ and $0.06 \%$ potassium $\left(\mathrm{K}_{2} \mathrm{O}\right)$. The $\mathrm{pH}$ was 8.22 and the percentage of organic matter was $28.83 \%$. The compost used in 2002 had: $13.48 \%$ carbon, $1.28 \%$ nitrogen $(\mathrm{N}), 2.23 \%$ phosphorus $\left(\mathrm{P}_{2} \mathrm{O}_{5}\right)$ and $0.05 \%$ potassium $\left(\mathrm{K}_{2} \mathrm{O}\right)$. The percentage of organic matter was $23.24 \%$ with a $\mathrm{pH}$ of 7.12 .

Cow manure from a cattle barn in the village of Kouaré was used as an organic fertilizer; urea $\left((\mathrm{CO})_{2} \mathrm{NH}_{2}\right.$, with $\left.46 \% \mathrm{~N}\right)$ and NPK in 12-24-12 were the mineral fertilizers employed. 


\section{Experimental design}

To investigate host plant resistance, biocontrol (Fusarium inoculum), fertilization (organic and mineral) and possible interactions on Striga emergence and sorghum growth and productivity, the following treatments were evaluated: (1) susceptible sorghum variety S29 (SUS), (2) resistant sorghum variety F2-20 (RES), (3) sorghum variety F2-20 with $30 \mathrm{~g}$ of sterilized growth medium planting hill ${ }^{-1}$ (RES+MED), (4) sorghum variety F2-20 with $30 \mathrm{~g}$ of Fusarium inoculum hill $^{-1}$ (RES+INO), (5) sorghum variety F2-20 with 5 tons of cow manure ha ${ }^{-1}$ (RES+MAN), (6) sorghum variety F2-20 with $200 \mathrm{~kg}$ of urea ha ${ }^{-1}$ (RES+URE), (7) sorghum variety F2-20 with $30 \mathrm{~g}$ of sterilized growth medium hill $^{-1}$ and 5 tons of cow manure ha ${ }^{-1}$ (RES+MED+MAN), (8) sorghum variety F220 with $30 \mathrm{~g}$ of sterilized growth medium hill ${ }^{1}$ and $200 \mathrm{~kg}$ of urea ha ${ }^{-1}$ (RES+MED+URE), (9) sorghum variety F2-20 with $30 \mathrm{~g}$ of Fusarium inoculum hill ${ }^{-1}$ and 5 tons of cow manure $\mathrm{ha}^{-1}$ (RES+INO+MAN) and (10) sorghum variety F2-20 with $30 \mathrm{~g}$ of Fusarium inoculum hill ${ }^{-1}$ and $200 \mathrm{~kg}$ of urea ha ${ }^{-1}$. The experimental design was a randomized complete block with four repetitions. In treatments not receiving urea or manure (SUS, RES, RES+MED and RES+INO), $100 \mathrm{~kg} \mathrm{ha}^{-1}$ of NPK was applied to the plots at sowing and $50 \mathrm{~kg} \mathrm{ha}^{-1}$ of urea was applied at booting stage of sorghum. The main plot consisted of four rows of $2.4 \mathrm{~m}$ length with $0.8 \mathrm{~m}$ between rows and $0.4 \mathrm{~m}$ between plants within rows. To avoid the influence of treatments on the results from one year to another, the second experiment (in 2002) was not set up on the same experimental plots from the previous year.

\section{Crop management and rainfall}

The trials were sown on 17 July 2001 and on 23 July 2002. Fusarium inoculum and the growth medium were incorporated into planting hills at sowing. Mineral fertilizers and manure were applied by spreading evenly over the experimental plot and incorporating into the soil. The individual treatment plots were separated by a ridge created immediately after planting to avoid plot-to-plot contamination through runoff water, etc. Plots were weeded twice [at 14 and 30 days after sowing (DAS)] with hoes before the emergence of $S$. hermonthica. Rainfall recorded in 2001 was $832.7 \mathrm{~mm}$ in 28 rain events and with $62.3 \%$ of rain falling during the crop growth period. In 2002, $693.7 \mathrm{~mm}$ of rainfall fell in 29 rain events with $57.9 \%$ falling during the crop growth period.

\section{Data collection and analysis}

Treatments combining two or more Striga control methods were called integrated Striga management (ISM) treatments. The following observations were made in the two central rows of each plot (10 hills, or a total area of $1.92 \mathrm{~m}^{2}$ ): (1) symptoms of fungal disease on sorghum, (2) weekly counts of emerged Striga plants from four to twelve weeks after the first emergence of Striga in the experiment, (3) visual estimation of vigour of emerged Striga plants (Haussmann et al., 2000) at 85 DAS, (4) weight of Striga dry biomass at sorghum harvest and (5) sorghum yield. Striga count data were used to calculate area under the Striga number progress curve (ASNPC, Haussmann et al., 2000).

A comparative economic analysis of treatments was performed. The costs used in this analysis were those of crop seed, the workforce, the mineral fertilizers and the cow manure. The price of a $50 \mathrm{~kg}$ bag of fertilizer (urea or NPK) including transportation was 15,000 F CFA ( 1 F CFA $=0.0017$ US $\$$ ). The manure and growth medium amounted to $15 \mathrm{~F}$ CFA kg${ }^{-1}$. The manpower at Kouaré station in 2001 - 2002 was 152.46 F CFA hour ${ }^{-1}$. The application time for manure and urea was one hour $\mathrm{ha}^{-1}$ and $10 \mathrm{~h} \mathrm{ha}^{-1}$ to incorporate 
Fusarium inoculum or growth medium into planting hills. The cost of sorghum grain in Kouaré area was $100 \mathrm{~F} \mathrm{CFA} \mathrm{kg}^{-1}$ in 20012002.

Data were checked for normality to determine if transformation was needed (Gomez and Gomez, 1984). Striga counts were $\log$-transformed $\left(\log _{10}(\mathrm{x}+1)\right)$ and Striga biomass was transformed by taking the square root of the individual values before performing ANOVA using the SAS program (SAS Institute, Cary, NC). Testing for significant differences between individual means of treatments was determined with the LSD's test at $\mathrm{P}<0.05$.

\section{RESULTS}

Effect of host plant resistance, biocontrol, and fertilizer on Striga infestation

Treatments did not significantly influence the date of Striga emergence in either cropping season. However, in 2002, experimental treatments reduced vigour of Striga plants at 85 DAS $(\mathrm{P}<0.0360)$ compared to the susceptible sorghum variety. Treatments combining sorghum resistance and urea; sorghum resistance, Fusarium inoculum and manure or urea (RES+URE, RES+INO+MAN or RES+INO+URE) significantly reduced the number of emerged Striga at 85 DAS as compared to the susceptible control (SUS) by $81 \%, 97.7 \%$ and $96.6 \%$, respectively (Table 2). ISM treatments including the resistant sorghum (RES), biocontrol (INO), and fertilizer (MAN, either manure or urea) had fewer emerged Striga than the resistant check (RES).

Striga plant vigour at 85 DAS was greatest $(\mathrm{P}<0.0001)$ on the susceptible sorghum variety (SUS) and the four ISM treatments (RES+MAN, RES+MED+URE, RES+INO+MAN and RES+INO+URE) significantly reduced Striga vigour in comparison with resistant control treatment (RES) in 2001 (Table 1). In 2002, Striga vigour at 85 DAS in susceptible and resistant plots (SUS, RES) were similar and significantly higher $(\mathrm{P}<0.0001)$ than that recorded in the seven ISM treatments (Table 2). With the exception of the treatment based on sorghum resistance with Fusarium inoculum (RES+INO), Striga vigour was reduced in ISM treatments in 2002 as compared to resistant sorghum treatment (RES).

The area under the Striga number progress curve (ASNPC) and Striga dry biomass were highest in the susceptible control (SUS) treatment in 2001 and in 2002 but only in 2002 did treatments significantly affect these Striga parameters (Table 2). With the exception of the treatment RES+MED+MAN, ASNPC was reduced by all ISM treatments when compared to the resistant sorghum treatment, but not always when compared to the susceptible sorghum treatment in $2002(\mathrm{P}<0.029)$. Treatments combining sorghum resistance, Fusarium inoculum and urea or manure (RES+INO+URE, RES+INO+MAN) reduced ASNPC by $94.5 \%$ and $96.4 \%$ whereas five other ISM treatments reduced ASNPC by 54$78 \%$, as compared to the susceptible control (SUS). Striga dry biomass at sorghum harvest was significantly reduced $(\mathrm{P}<0.001)$ by ISM treatments combining sorghum resistance with one or two components including manure, urea and Fusarium inoculum in 2002. Striga biomass was reduced by $100 \%$ by ISM treatments combining sorghum resistance with urea or Fusarium inoculum or both (RES+URE, RES+INO, RES+INO+URE) (Table 2).

Effects of host plant resistance, biocontrol, and fertilizer on sorghum yield

No fungal disease was observed on sorghum plants during either cropping season. ANOVA revealed significant differences $(\mathrm{P}<0.001)$ between treatments for the total 
biomass and grain yield of sorghum (Table 3 ). In 2001, the total biomass obtained with the susceptible control (SUS) was significantly lower than all other treatments which were not significantly different among each other. In 2002, the total biomass obtained with susceptible and resistant control treatments were lowest and not statistically different from each other. Four ISM treatments combining either sorghum resistance with Fusarium inoculum and manure or urea (RES+INO+MAN, RES+INO+URE) or sorghum resistance with growth medium and manure or urea (RES+MED+MAN, RES+MED+URE) significantly improved sorghum total biomass by $37-60 \%$, as compared to the resistant control (RES). Sorghum grain yield of the susceptible control (SUS) was lowest in both years (Table 3). Only the grain yield from the treatment combining sorghum resistance with growth medium and urea (RES+MED+URE) obtained in 2001 was significantly different from that of the resistant control (RES). On the other hand in 2002, sorghum grain yield was higher with ISM treatments as compared to the susceptible control with the exception of the treatment combining sorghum resistance with manure (RES+MAN). ISM treatments lead to an increase of grain yield of $88.8 \%$ to $134.4 \%$ compared to the susceptible control treatment (SUS).

Profitability of Striga control employing host plant resistance, biocontrol, and fertilizer

The cost of treatments to control Striga may be ranked into three distinct groups (Table 4). The first group is the crop variety, susceptible S 29 (SUS) and resistant F2-20 (RES) whose costs were 45,305 F CFA ha ${ }^{-1}$. The second group consisted of four treatments combining sorghum resistance with either growth medium, manure, urea or Fusarium inoculum (RES+MED, RES+MAN, RES+URE, RES+INO) whose costs varied between 60,000 and 75,000 F CFA ha ${ }^{-1}$. The third cluster was composed of treatments combining sorghum resistance with two components (RES+MED+MAN, RES+MED+ URE, RES+INO+MAN, RES+INO+URE) leading to costs variation between 121,000 and $136,000 \mathrm{~F}_{\mathrm{CFA} \mathrm{ha}}{ }^{-1}$. The gross income gained was lowest in the susceptible sorghum treatment (SUS) in both 2001 and 2002. The highest gross incomes in 2001 (ranging from 70,310 to 82,680 $\mathrm{F} \mathrm{CFA} \mathrm{ha}^{-1}$ ) and 2002 (from 91,150 to $109,380 \mathrm{~F} \mathrm{CFA} \mathrm{ha}^{-1}$ ) were obtained with five ISM treatments (RES+MED+MAN, RES+URE, RES+MED+URE, RES+INO+ MAN and RES+INO+URE). Regarding the profitability of Striga control, a positive profit margin was obtained in 2001 only with three treatments, namely the resistant sorghum variety (RES), sorghum resistance with urea (RES+URE) and sorghum resistance with Fusarium inoculum (RES+INO) (Table 4). In addition to these three treatments, the treatment combining sorghum resistance and growth medium (RES+MED) also allowed a positive profit in 2002. However, a net gain of more than $10,000 \mathrm{~F} \mathrm{CFA} \mathrm{ha}^{-1}$ was generated in 2001 only by a resistant sorghum variety and a resistant sorghum variety with urea whereas in 2002, a net gain of more than $10,000 \mathrm{~F} \mathrm{CFA} \mathrm{ha}^{-1}$ was generated only by a resistant sorghum variety with urea and a resistant sorghum variety with Fusarium inoculum. ISM treatments including three components including sorghum resistance, manure, urea, growth medium and Fusarium inoculum and the treatment based on sorghum resistance associated with manure all led to negative net profit for both cropping seasons, due to their relatively high costs (Table 4). 
Table 1: Parameters of $S$. hermonthica emergence, development and biomass in 2001 in response to different control treatments.

\begin{tabular}{|c|c|c|c|c|c|}
\hline Treatments & $\begin{array}{c}\text { Striga } \\
\text { emergence, } \\
\text { DAS } \\
\end{array}$ & $\begin{array}{c}\text { Number of } \\
\text { Striga / } \mathrm{m}^{2} \\
85 \mathrm{DAS} \\
\end{array}$ & $\begin{array}{c}\text { Vigour of } \\
\text { Striga } \\
\text { 85 DAS } \\
\end{array}$ & ASNPC & $\begin{array}{c}\text { Dry biomass of } \\
\text { Striga } \\
(\mathrm{kg} / \mathrm{ha}) \\
\end{array}$ \\
\hline SUS & 56.50 & $0.88^{!}(6.75)^{\S}$ & $4.75 \mathrm{a}^{8}$ & 1508 & $10.74^{\$}(123.70)$ \\
\hline RES & 56.00 & $0.80 \quad(5.50)$ & $3.50 \mathrm{~b}$ & 977 & $7.17(52.08)$ \\
\hline RES+MED & 61.80 & $0.65 \quad(5.00)$ & $3.00 \mathrm{bc}$ & 810 & $7.50(55.99)$ \\
\hline RES+MAN & 63.80 & $0.72 \quad(7.25)$ & $2.50 \mathrm{~cd}$ & 946 & $6.00(45.57)$ \\
\hline RES+URE & 61.20 & $0.54(2.75)$ & $2.75 \mathrm{bcd}$ & 588 & $5.07(32.55)$ \\
\hline RES+MED+MAN & 69.80 & $0.54(3.25)$ & $2.75 \mathrm{bcd}$ & 899 & $5.60(39.06)$ \\
\hline RES+MED +URE & 61.50 & $0.69(4.75)$ & $2.50 \mathrm{~cd}$ & 1009 & 7.38 (55.99) \\
\hline RES+INO & 58.90 & $0.66(3.50)$ & $3.50 \mathrm{~b}$ & 787 & $8.01(117.19)$ \\
\hline RES+INO+MAN & 66.00 & $0.33(2.00)$ & $2.50 \mathrm{~cd}$ & 546 & $3.10(13.02)$ \\
\hline RES+INO+URE & 68.80 & $0.37(1.50)$ & $2.00 \mathrm{~d}$ & 592 & $7.36(52.08)$ \\
\hline Mean & 62.40 & 0.617 & 2.98 & 886. & 6.79 \\
\hline LSD & 14.27 & 0.5139 & 0.8019 & 834.4 & 5.175 \\
\hline
\end{tabular}

Sign. Level the number of emerged Striga hermonthica; §: Means in brackets are back-transformations of number or dry biomass of emerged Striga hermonthica; \$: Square root $(\mathrm{x}+1)$ transformations, $\mathrm{x}$ is Striga dry biomass; \&: Means followed by the same letter are not significantly different according to LSD's test at 5\%.

Table 2: Parameters of $S$. hermonthica emergence, development and biomass in 2002 in response to the different control treatments.

\begin{tabular}{|c|c|c|c|c|c|}
\hline Treatments & $\begin{array}{c}\text { Striga } \\
\text { emergence, } \\
\text { DAS }\end{array}$ & $\begin{array}{l}\text { Number? }^{?} \text { of } \\
\text { Striga / } \mathbf{m}^{2} \\
85 \mathrm{DAS}\end{array}$ & $\begin{array}{l}\text { Vigour of } \\
\text { Striga } \\
\text { 85 DAS }\end{array}$ & ASNPC & $\begin{array}{c}\text { Dry biomass of } \\
\text { Striga (kg/ha) }\end{array}$ \\
\hline$\overline{\text { SUS }}$ & 55.60 & $1.08 \mathrm{a}^{!}(14.50)^{\S}$ & $4.75 \mathrm{a}$ & $833 \mathrm{ab}$ & $8.90 \mathrm{a}^{\$}(85.94)^{?}$ \\
\hline RES & 67.30 & $1.02 \mathrm{ab}(18.00)$ & $4.00 \mathrm{ab}$ & $1223 \mathrm{a}$ & 3.62 bc (19.53) \\
\hline RES+MED & 85.10 & $0.33 a b c(1.67)$ & $3.00 \mathrm{~cd}$ & $263 \mathrm{bc}$ & $7.25 \mathrm{ab}(52.08)$ \\
\hline RES+MAN & 64.30 & 0.98 ab (14.33) & $2.50 \mathrm{~d}$ & $382 \mathrm{bc}$ & 3.14 bc (13.89) \\
\hline RES+URE & 73.80 & $0.27 \mathrm{bc}(2.75)$ & $2.25 \mathrm{~d}$ & $180 \mathrm{bc}$ & $1.00 \mathrm{c}(0.00)$ \\
\hline RES+MED+MAN & 63.50 & $0.58 \mathrm{abc}(4.25)$ & $2.75 \mathrm{~cd}$ & $611 a b c$ & $3.10 \mathrm{c}(13.02)$ \\
\hline RES+MED+URE & 65.00 & $0.44 a b c(2.50)$ & $2.75 \mathrm{~cd}$ & $221 \mathrm{bc}$ & $2.57 \mathrm{c}(13.02)$ \\
\hline RES+INO & 74.30 & $0.53 \mathrm{abc}(3.25)$ & $3.50 \mathrm{bc}$ & $200 \mathrm{bc}$ & $1.00 \mathrm{c}(0.00)$ \\
\hline RES+INO+MAN & 66.60 & 0.08 c $(0.33)$ & $2.50 \mathrm{~d}$ & $30 \mathrm{c}$ & $3.35 \mathrm{bc}(26.04)$ \\
\hline RES+INO+URE & 135.50 & 0.15 c $(0.50)$ & $2.25 \mathrm{~d}$ & $46 \mathrm{c}$ & $1.00 \mathrm{c}(0.00)$ \\
\hline Mean & 75.10 & 0.545 & 3.03 & 391 & 3.49 \\
\hline LSD & 79.03 & 0.6726 & 0.7799 & 702.4 & 3.458 \\
\hline Sign. Level & ns & * & $* *$ & $*$ & $* *$ \\
\hline
\end{tabular}


Table 3: Sorghum biomass and grain yield in response to the different Striga control treatments.

\begin{tabular}{|c|c|c|c|c|}
\hline \multirow[t]{2}{*}{ Treatments } & \multicolumn{2}{|c|}{ Total biomass of sorghum (kg/ha) } & \multicolumn{2}{|c|}{ Sorghum grain yield (kg/ha) } \\
\hline & 2001 & 2002 & 2001 & 2002 \\
\hline SUS & $25.86^{\$} \mathrm{a}^{!}(763)^{?}$ & 38.25 a $(1527)$ & 13.95 a (221.4) & 13.91 a $(195.3)$ \\
\hline RES & 47.87 b (2298) & $43.19 \mathrm{ab}(1875)$ & $24.67 \mathrm{bc}(610.7)$ & $21.49 \mathrm{~b}(462.2)$ \\
\hline RES+MED & 44.78 b (2018) & 50.35 bc (2643) & $23.22 \mathrm{~b} \quad(541.7)$ & 26.26 c $\quad(696.7)$ \\
\hline RES+MAN & 46.73 b (2201) & $50.25 \mathrm{bc}(2552)$ & 25.97 bcd (677.1) & $26.21 \mathrm{bc}(696.6)$ \\
\hline RES+ URE & $51.36 \mathrm{~b}(2734)$ & 53.91 bcd (2917) & $27.79 \mathrm{~cd} \quad(774.7)$ & $30.15 \mathrm{~cd}(911.5)$ \\
\hline RES+MED+MAN & 43.39 b (1888) & 59.96 cde $(3607)$ & $26.25 \mathrm{bcd}(703.1)$ & $30.35 \mathrm{~cd}(924.5)$ \\
\hline RES+MED+URE & $43.43 \mathrm{~b}(1888)$ & $62.28 \mathrm{de}$ (3893) & $28.64 \mathrm{~d}$ & $29.87 \mathrm{~cd}(911.5)$ \\
\hline RES+INO & $48.13 \mathrm{~b}(2357)$ & 53.66 bcd (2995) & $24.70 \mathrm{bc}$ & 26.49 c $(709.6)$ \\
\hline RES+INO+MAN & 48.85 b (2409) & $62.23 \mathrm{de}$ (3893) & $28.29 \mathrm{~cd}$ & $32.49 \mathrm{~d}(1067.7)$ \\
\hline RES+INO+URE & $51.54 \mathrm{~b}(2663)$ & $68.18 \mathrm{e}$ & $27.27 \mathrm{~cd} \quad(755.2)$ & $32.60 \mathrm{~d}(1093.8)$ \\
\hline Mean & 45.19 & 54.2 & 25.07 & 26.98 \\
\hline LSD & 8.712 & 11.23 & 3.889 & 4.752 \\
\hline Sign. Level & $*$ & * & * & * \\
\hline
\end{tabular}

Sign. level: significance level (one-way ANOVA), P: $(*)<0.01$. !: Means followed by the same letter are not significantly different according to LSD's test at 5\%. \$ : Square root $(x+1)$ transformations, $x$ is total biomass or grain yield of sorghum ?: Means in brackets are back-transformations of total biomass or grain yield of sorghum.

Table 4: Economic analysis of the cost/benefit of treatments for controlling Striga hermonthica.

\begin{tabular}{lccccc}
\hline Treatments & $\begin{array}{l}\text { Cost of } \\
\text { treatments } \\
\text { F CFA ha }^{-1}\end{array}$ & \multicolumn{2}{c}{$\begin{array}{c}\text { Gross income } \\
\text { F CFA ha }\end{array}$} & \multicolumn{2}{c}{$\begin{array}{c}\text { Net gain/loss from Striga } \\
\text { control } \\
\text { F CFA ha }^{-1}\end{array}$} \\
\cline { 3 - 6 } & & 22,140 & 19,530 & $-23,165$ & $-25,775$ \\
\hline SUS & 45,305 & 61,070 & 46,220 & 15,765 & 915 \\
RES & 45,305 & 54,170 & 69,660 & $-6,722$ & 8,768 \\
RES+MED & 60,892 & 67,710 & 69,660 & $-7,442$ & $-5,492$ \\
RES+MAN & 75,152 & 77,470 & 91,150 & 17,318 & 30,998 \\
RES+URE & 60,152 & 70,310 & 92,450 & $-65,734$ & $-43,594$ \\
RES+MED+MAN & 136,044 & 82,680 & 91,150 & $-38,364$ & $-29,894$ \\
RES+MED+URE & 121,044 & 61,200 & 70,960 & 308 & 10,068 \\
RES+INO & 60,892 & 80,730 & 106,770 & $-55,314$ & $-29,274$ \\
RES+INO+MAN & 136,044 & 75,520 & 109,380 & $-45,524$ & $-11,664$ \\
RES+INO+URE & 121,044 & & & & $\mathbf{2 0 0 2}$ \\
\hline
\end{tabular}

\section{DISCUSSION}

The absence of fungal disease symptoms on sorghum plants confirmed that sorghum is immune to $F$. oxysporum isolate 34-FO. With respect to emergence of the parasite and its development, no consistent differences were seen between the two sorghum varieties in the two years. The resistant sorghum variety had significantly higher grain yield than the susceptible variety in both years but still relatively high numbers of emerged Striga plants, which suggests that this variety is more tolerant to (than resistant to) Striga at this location. Despite the absence of significant differences between treatments for the date of Striga emergence, two ISM 
treatments delayed Striga emergence about 2 weeks in 2001 (RES+MED+MAN, RES+INO+URE) and more than 3 weeks in 2002 (RES+MED, RES+INO) when compared to the susceptible control (SUS). Some components of ISM such as the growth medium and Fusarium inoculum may affect Striga seed germination, attachment or underground growth stages of Striga seedlings (Yonli et al., 2006). The results from counts of Striga plants showed that application of urea (96 $\mathrm{kg} \mathrm{N} \mathrm{ha}^{-1}$ ) led to a reduction of emerged Striga at 85 DAS whereas cow manure did not reduce Striga emergence or biomass. Our results confirm the observation of Showemimo (2007) who showed in a pot experiment a negative and significant correlation between level of $\mathrm{N}$ fertilizer and Striga counts. Working in the Niger, Hess (1989) found that application of nitrogen fertilizer (50 kg ha-1 at sowing and again at the tillering growth stage) restricted Striga number and dry biomass whereas growth was profuse on the unfertilized crop. In the Sudan, Bebawi and Farah (1981) reported that application of nitrogenous fertilizer significantly reduced both Striga number and dry weights. In vitro studies by Pesch and Pieterse (1982) showed reduction in seed germination percentage and radicle length of $S$. hermonthica in the presence of urea concentrations of $\geq 200 \mathrm{mg} \mathrm{L}^{-1}$ under both acid and alkaline conditions. The amount of nitrogen in our cow manure was presumably insufficient to affect the number of emerged Striga plants in this experiment. Dembélé and Kayentao (2002) observed that the number of emerged Striga plants in plots fertilized with manure was higher than that recorded in plots fertilised with mineral fertilizer. This study shows that ISM treatments including sorghum resistance and urea or manure combined with Fusarium inoculum have the potential to reduce Striga emergence considerably. A similar study in Nigeria, showed that a combination of a resistant sorghum variety and mycoherbicide based on $F$. oxysporum (isolate PSM 197) significantly reduced the number of emerged Striga by about $95 \%$ compared to a susceptible control sorghum variety (Marley et al., 2004). Our observations show the potential of successful Striga management based on $F$. oxysporum 34-Fo and the application of urea. As data for the two years were variable, we could not show a synergistic effect between cow manure and Fusarium inoculum in terms of Striga control and sorghum yield. However, the application of manure and compost to fields to increase soil organic matter is to be encouraged as this improves soil structure, nutrient supply, water holding capacity, and reduces erosion. The comparison of treatment means for emerged Striga at 85 DAS, vigour and ASNPC of Striga in 2002 showed that the treatment combining sorghum resistance and growth medium (RES+MED) was as effective as treatments including Fusarium inoculum. This effectiveness was probably due to the amount (937.5 kg ha ${ }^{-1}$ ) of sterilized compost applied to each planting hole. Indeed, this amount may have constituted micro dose of wellcomposted organic fertilizer for enhanced sorghum growth as well as a growth medium for microbial agents present in the soil. Berner et al. (1996) investigated soil samples from Nigeria and demonstrated that natural soil suppressiveness to $S$. hermonthica is of microbial origin. So, the incorporation of uninoculated growth medium in the soil may boost the growth of edaphic pathogens that then attack Striga.

The basal doses of $100 \mathrm{~kg} \mathrm{NPK} \mathrm{ha}^{-1}$ of and $50 \mathrm{~kg}$ urea ha ${ }^{-1}$ in the treatments without fertilizers are those promoted by extension for cropping in poor soils. ISM plots fertilised with only urea, urea plus growth medium and urea or manure associated with Fusarium inoculum allowed an improvement of sorghum grain yield of at least $15 \%$ in 2001 and at least $97 \%$ in 2002. The application of just Fusarium inoculum significantly improved sorghum grain yield by $54 \%$ in 2002. Among these treatments, the application 
of urea or Fusarium inoculum led to a positive financial return in 2001 and in 2002. However, the cost of production of the inoculum has not been taken into account in this analysis. We did not estimate the cost of production of the inoculum, but it is clear that this requires skilled labour, laboratory materials, an autoclave and incubation chambers. Therefore, the net gain with Fusarium inoculum treatment in reality should be lower, because of the cost of inoculum production that was not taken into account in the economic analysis.

Although the resistant sorghum variety did not significantly reduce Striga, its grain yield was always significantly higher and the net gain was always positive as compared to the susceptible variety. This result stresses the importance of the use of varietal resistance as a first and low cost option to control Striga and or mitigate its negative effect. A combination of Fusarium inoculum with mineral or organic fertilizers was effective in reducing number and growth of emerged Striga and increasing sorghum yield. Thus, the application of mineral/organic fertilizers and the incorporation of Fusarium inoculum can be beneficial for controlling Striga and improving sorghum yields. The most interesting treatment from this study in economic terms is the combination of sorghum resistance with application of urea. Despite the high cost of treatments with high doses of urea and cow manure, their use should be encouraged because organic fertilizer improves the physical properties and long term soil health and fertility of degraded soils which are heavily infested by $S$. hermonthica, while mineral fertilizer provides available soil nutrients and immediate positive effects on growth of the host crop. The combination of the application of organic and mineral fertilizers in the same treatment, although not studied here, could be included in future studies. ISM treatments that include Fusarium inoculum can reduce Striga infestation and alleviate Striga damage which in turn can lead to sorghum yield increase. Although the effect of Fusarium inoculum with a resistant sorghum variety in terms of Striga control and sorghum yield improvement is promising, the marginal rate of return is lower than a resistant sorghum variety only and a resistant variety with urea. This suggests that in its current form, Fusarium inoculum is not a viable option for farmers and the Fusarium inoculum method probably needs improvement in efficacy of control as well as ways in which it can be produced. The analysis of production costs and profit margins from treatments with urea showed that, to control Striga infestation under field conditions, one needs to invest a considerable sum that may not immediately be recovered through increased yield. The very low profit margin is an important constraint for the adoption of the technology (high doses of urea) by farmers and broader participatory testing and evaluation in farmers' fields should be performed in order to determine feasibility of the technology.

\section{ACKNOWLEDGEMENTS}

We are grateful to International Foundation of Science (IFS) which funded this study. We also thank the "Institut de l'Environnement et de Recherches Agricoles (INERA)" of Burkina Faso for the infrastructure allowing us to carry out this study. The writing of the manuscript has been facilitated by funding provided by the Food Security Center from the University of Hohenheim, Germany and a four month visit of D. Yonli to the International Crops Research Institute for the Semi-Arid Tropics (ICRISAT)-Bamako, Mali.

\section{REFERENCES}

Abbasher AA, Hess DE, Sauerborn J. 1998. Fungal pathogens for biological control of Striga hermonthica on sorghum and pearl millet in West Africa. African Crop Science Journal, 6: 179-188. 
Ahonsi MO, Berner DK, Emechebe AM, Lagoke ST. 2002. Selection of rhizobacterial strains for suppression of germination of Striga hermonthica (Del.) Benth. seeds. Biological Control, 24: 143-152.

Bebawi FF, Farah AF. 1981. Effects of nitrophoska and atrazine on relations between Sorghum bicolor and Striga hermonthica. Expl. Agric., 17: 425-430.

Berner D, Carsky R, Dashiell K, Kling J, Manyong V. 1996. A land management based approach to integrated Striga hermonthica control in sub-Saharan Africa. Outlook on Agriculture, 25: 157164.

Ciotola M, Ditommaso A, Watson AK. 2000. Chlamydospore production, inoculation methods and pathogenicity of Fusarium oxysporum M12-4A, a biocontrol for Striga hermonthica. Biocontrol Science \& Technology, 10: 129-145.

Dembélé B, Kayentao M. 2002. Etude de l'association sorgho/niébé comme moyen de lutte contre le Striga hermonthica. Pp 80-85 In Integrated Striga Management Technologies: From Research to Farmers, Lagoke STO, M'Boob SS (eds). Proceedings of the $4^{\text {th }}$ general workshop of the Pan African Striga Control Network (PASCON), 28 Oct.-1 Nov. 1996, Bamako, Mali.

Gomez KA, Gomez AA. 1984. Statistical Procedures for Agricultural Research $\left(2^{\text {nd }}\right.$ Edn). John Wiley \& Sons, Inc: New York; $680 \mathrm{p}$.

Gressel J, Hanafi A, Head G, Marasas W, Obilana AB, Ochanda J, Souissi T, Tzotzos G. 2004. Major heretofore intractable biotic constraints to African food security that may be amenable to novel biotechnological solutions. Crop Protection, 23: 661-689.

Haussmann BIG, Hess DE, Welz HG, Geiger HH. 2000. Improved methodologies for breeding Striga-resistant sorghums. Field Crops Research, 66: 185-211.
Hess DE. 1989. Resistance to Striga hermonthica (Del.) Benth. in Sorghum. Purdue University; 240 pp.

Marley PS, Aba DA, Shebayan JAY, Musa R, Sanni A. 2004. Integrated management of Striga hermonthica in sorghum using a mycoherbicide and host plant resistance in the Nigerian sudano-sahelian savanna. Weed Research, 44: 157-162.

Olivier A, Ramaiah KV, Leroux GD, 1992. Evaluation de lignées de sorgho (Sorghum bicolor) pour leur résistance à la mauvaise herbe parasite Striga hermonthica au Burkina Faso. Phytoprotection, 73: 13-23.

Parker C, Riches CR. 1993. Parasitic Weeds of the World: Biology and Control. CAB International: Wallingford, UK; 332 p.

Pesch C, Pieterse AH. 1982. Inhibition of germination in Striga by means of urea. Experientia, 38: 559-560.

Scholes DJ, Press CM. 2008. Striga infestation of cereal crops - unsolved problem in resource limited agriculture. Plant Biology, 11: 180-186.

Sedogo PM, Lompo F, Bonzi M, Bado BV, Segda Z. 1999. Compostage en fosse des résidus de récoltes (sorgho, mil, maïs). Fiche technique réalisée en milieu paysan et adaptée aux conditions des producteurs Burkinabé, 4 pp.

Showemimo FA. 2007. Relationships between sources and levels of nitrogen fertitilization and the control of Striga hermonthica in sorghum. International Journal of Agricultural Research, 2: 170174.

Traoré H, Yonli D. 2001. Striga et autres adventices : perception paysanne et inventaire des méthodes endogènes de lutte dans l'Est du Burkina Faso. Science et Technique, Sciences Naturelles et Agronomie, 25: 46-59.

Van Mourik TA. 2007. Striga hermonthica Seed Bank Dynamics: Process Quantification and Modelling. 
Wageningen University: Wageningen; $123 \mathrm{p}$.

Van Mourik TA, Bianchi FJJA, Van der Werf W, Stomph TJ. 2008. Long-term management of the hemi-parasitic weed Striga hermonthica - strategy evaluation with a spatio-temporal population model. Weed Research, 48: 329-339.

Yonli D, Traore H, Hess DE, Abbasher AA, Boussim IJ. 2004. Effect of growth medium and method of application of Fusarium oxysporum on infestation of sorghum by Striga hermonthica in
Burkina Faso. Biocontrol Science \& Technology, 14: 417-421.

Yonli D, Traoré H, Hess DE, Sankara P, Sereme P. 2006. Effect of growth medium, burial distance and depth of Striga seeds on efficacy of Fusarium isolates to control Striga hermonthica in Burkina Faso. Weed Research, 46: 73-81.

Yonli D, Traoré H, Sereme P, Hess DE, Sankara P. 2010. Pathogenicity of Fusarium isolates to Striga hermonthica in Burkina Faso. Pakistan Journal of Biological Sciences, 13: 201-208. 